\title{
Do Enforcement, Religiosity and Peer Influence Zakah Compliance Behavior?
}

\author{
Saeed Awadh Bin-Nashwan ${ }^{1}$, Hijattulah Abdul-Jabbar ${ }^{1} \&$ Saliza Abdul Aziz ${ }^{1}$ \\ ${ }^{1}$ Tunku Puteri Intan Safinaz School of Accountancy, Universiti Utara Malaysia, Sintok, Malaysia \\ Correspondence: Saeed Awadh Bin-Nashwan, Tunku Puteri Intan Safinaz School of Accountancy, Universiti Utara \\ Malaysia, 06010 Sintok, Kedah, Malaysia.
}

Received: July 2, 2019

doi:10.5430/ijfr.v10n6p42
Accepted: July 28, 2019

Online Published: August 8, 2019

URL: https://doi.org/10.5430/ijfr.v10n6p42

\begin{abstract}
Although Zakah (Islamic tax) is considered to be a cornerstone of Islamic social system and mechanism for eradicating poverty among Muslim communities, the realization of noble socio-economic objectives of Zakah in most Muslim countries have so far remained a mirage. They are unable to bring out the destitute poor from the poverty trap and help the oppressed to be a self-reliant as possible. Low Zakah collection is one of the most crucial reasons behind this phenomenon. Yemen, for instance, is one of the poorest low-income countries in the world. In such a hard situation, Zakah has failed to appropriately fit as a fiscal instrument in fighting the plight of poverty. Therefore, this study aims to examine the determinants of Zakah payers' decision to comply with Zakah laws. A Survey questionnaire was administered to 500 business owners (Zakah payers) out of which 274 usable questionnaires for further analysis. Based on PLS-SEM outcomes, the study revealed that Islamic religiosity and peer influence are significantly related to business Zakah compliance, while law enforcement had no influence on compliance. The findings are relevant to Zakah authorities in Yemen and Muslim countries to focus their attention on formulation of policies to further boost Zakah collection.
\end{abstract}

Keywords: business Zakah, compliance behavior, Muslims, poverty

\section{Introduction}

In Muslim countries, apart from income tax, Zakah has emerged as a critical Islamic fiscal instrument that has recently attracted scholarly as well as Muslim communities' interest, to eradicate the social injustices in the community that need rectification and compensation (Al Haq \& Abd. Wahab, 2017). Literary, Zakah is an Arabic word which carries several meanings, such as cleanness, growth, purification and increase (Ahmed, 2004; Wahab \& Rahman, 2011). As one of the five pillars of Islamic faith, Zakah constitutes a religious obligation for a Muslim who meets the necessary criteria of wealth. Ordering of Zakah payment is basically a duty imposed since the early days of Islam. In simple sense, Zakah is the wealth transfer compulsorily from a surplus unit (rich people) to a deficit unit (poor people) as prescribed by the Holy Quran (Al-Qardawi, 2000).

As a result of the prevalence of severe poverty recorded in Muslim developing countries, many attempts have been done in place by some successive governments to effectively combat the plight of poverty, but little has been achieved. However, some scholars have argued that religious belief has a considerable effect and could well be utilized for crack the hard nut of poverty in such these communities (Sohag et al., 2015). Consequently, Zakah funds would be one of the best alternatives to eradicate poverty and achieve economic prosperity more especially in oppressed Muslim societies. Crucially, it has been claimed that Zakah, if well implemented, would be the 'silver bullet' in which yield an interesting outcome in social security system of an unfortunate and less privileged community (Sohag et al., 2015).

Admiringly, Heikal et al. (2014) argued that the worldwide collection of Zakah might generate some US\$600 billion annually if properly managed. Globally, however, it has been acknowledged that several Muslim countries suffer from a wide gap between desired and real Zakah performance (Alosaimi et al., 2017; Bin-Nashwan et al., 2016; Doktoralina \& Bahari, 2017; Saad et al., 2019). Therefore, this problem has been allegedly caused by some issues, one of which is low Zakah compliance among Muslims toward such a crucial Islamic duty. In Yemen, for instance, legal and administrative efforts have been made by the government to tackle the issue of low Zakah compliance (e.g., Zakah Law No. 2 of 1999). However, Zakah collection has unabatedly remained weak and disappointing (The 
General Directorates of Zakah Obligations (GDZO), 2016). Specifically, the contribution of Zakah on business to total state Zakah revenue have dropped dramatically over the last years; in 2011 was $45 \%$ then declined to $39 \%$ and 36\% in 2014 and 2016 respectively (GDZO, 2011-2016).

Theoretically, behavioral intention has been the mainstay of Zakah compliance literature, and it has dwelled so much based on confirming the suitability of some prevailing theoretical models, such as reasoned action and planned behavior models, while neglecting the actual behavior of Zakah compliance among Muslims (Bidin \& Idris, 2007; Haji-Othman \& Fisol, 2017). In the course of this, a study of Bidin et al. (2009) contended that further research on Zakah compliance must be moved beyond examining "intention" since it is a precursor to the actual behavior. In addition, there is lack of previous studies that have examined empirically Zakah compliance in Muslim Middle Eastern countries, particularly Yemen (Bin-Nashwan et al., 2016). As a result, the present study aims to answer a call for more research on the actual Zakah compliance behavior to provide an in-depth understanding of economic and behavioral determinants (i.e., law enforcement, Islamic religiosity and peer influence) that influence Zakah payers' compliance behavior in a typical Islamic set-up like Yemen. Thus, it is expected the results of this study would be useful for the relevant Zakah authority not only in Yemen but also in other Muslim countries. The study also adds value to the body of the scanty literature in this domain. The paper is structured as follows. Section 2 provides a review of related prior studies and hypotheses development. Subsequently, the study method is discussed in Section 3, followed by the findings and discussion in Section 4. Lastly in Section 5, the study ends with conclusion, implications and limitations.

\section{Literature Review and Hypotheses Development}

In this section, the paper presents the theoretical framework and hypotheses of the study. The study emerges with a wider clue derived from various aspects, including economic and social psychological approaches. Thus, the following sub-sections have overview of the determinants (law enforcement, Islamic religiosity and peer influence) influence Zakah payers' decision to comply with Zakah payment.

\subsection{Law Enforcement and Business Zakah Compliance}

A compliance behavior through economic approach is basically explained based on the rational choice. It was originally stemming from tax compliance literature (Chau \& Leung, 2009). The deterrence effect of penalty structure and probability of detection determines the monetary cost of compliance which drives compliance behavior (Castro \& Scartascini, 2015). It can be assumed that Zakah payers' decision to comply is made in an environment of uncertainty based on the fear of being caught and punished. In line with the deterrence approach, sanctions and threat of detection and punishment are introduced to maximize policies in curbing unwanted illegal behavior and motivation Zakah compliance. In Yemen, Zakah is one of the important components in its fiscal system, where is imbued with the feature of obligation and compulsion to achieve economic development for the nation (Bin-Nashwan et al., 2017). Penalty structure has been regulated in the Yemeni system for Zakah noncompliance, but still ineffective with weak enforcement by the responsible authority of Zakah (GDZO, 2016).

Unlike tax compliance studies, past Zakah literature concerning the association between law enforcement and Zakah compliance is still minimal. Idris (2002) argued that when all Zakah payers act and behave in accordance with an effective Zakah law, their compliance behavior would be better. It could be claimed that Zakah payers' compliance would improve if law enforcement has a strict action against violated behavior. Generally, the findings of the extant prior studies have suggested that law enforcement is significantly and positively related to Zakah payers' decisions to comply with Zakah instructions (Bidin, 2008; Farah et al., 2017; Khamis \& Yahya, 2015). However, limited literature on Zakah compliance determinants, including law enforcement, in Yemen. Accordingly, the present study intends to test the influence of enforcement on Yemenis' compliance behavior with Zakah laws. As postulated by deterrence model, it can be assumed that a high level of Zakah compliance when a Zakah payer perceives law enforcement with penalties if being caught evading Zakah. The more effective law enforcement the more compliance behavior. Hence, the perceived law enforcement may improve business owners' (Zakah payers) compliance behavior as formulated below:

H1. Law enforcement has a positive influence on business Zakah compliance

\subsection{Islamic Religiosity and Business Zakah Compliance}

Another important fundamental determinant of Zakah compliance behavior is religiosity. Basically, Zakah is financial worship and as such religiosity cannot be discounted as main part of Zakah compliance determinants (Diabi, 1993). Pope and Mohdali (2010) defined religiosity as "the extent to which an individual is committed to the religion he/she professes and its teachings, such that individual attitudes and behaviors reflect this commitment". Idris et al. 
(2012) suggested that Muslims' decision to comply with Zakah might rely on a wider range of components (e.g., spiritual factors). This is due to Zakah itself stems from religious faith established by God. Accordingly, it can be concluded that an individuals' religious belief is always used in their daily activities although to varying extents.

Religiosity is regarded as individuals' internal moral enforcement mechanism; where it may inhibit immoral and illegal behavior (Torgler, 2006). The results of the past literature have further supported the significant influence of religiosity on certain behaviors, such as minimize cheating rates (Bloodgood et al., 2008) and boosting tax compliance behavior (Mohdali \& Pope, 2014). In Zakah literature, religiosity is a fundamental determinant because commitment to pay Zakah is inherently one of the main principles of Islam's religion itself. Empirically, the past literature has revealed a positive significant relationship between Islamic religiosity and compliance behavior of Zakah payers (Abdullah \& Sapiei, 2018; Azman \& Bidin, 2015; Idris et al., 2012), while Idris (2002) found a negative relationship between religiosity and compliance behavior. From the foregoing it can be deduced that a Zakah payer with high religious faith would be more inclined to have a more favorable behavior to comply with a Zakah than Zakah payer with low religious values. It is therefore appropriate to posit that:

$\mathrm{H} 2$. Islamic religiosity has a positive influence on business Zakah compliance

\subsection{Peer Influence and Business Zakah Compliance}

Peer influence can be defined as pressure from close people such as friends, family, business peer and partner who have an influence on an individual decision making (Bobek et al., 2013). A rational explanation provided by social psychologists is that an individual is more likely to evade a commitment when he/she perceives peers and close referents are doing so (Chan et al., 2000). Further, individuals might consider violating the law that observed from peer, because they might pursuer justice by engaging in the same activity (Davis et al., 2003). This is consistence with social influence theory. It posits that human behavior is affected by the surrounded environment either intentionally or unintentionally as proposed Kelman (1958) and then improved by Bandura (1977). From an Islamic viewpoint, a person can be evaluated considerably based on his/her reference group that he/she accompanies, and this what the Prophet (peace be upon him) was alluded to.

In a similar trend, it can be concluded that Zakah payers' important referents might determine how Zakah payers should behave. Compliance behavior literature suggested that those individuals who live within a society shirked commitment, would highly be expected to act similarly. The relationship between peer influence and compliance behavior has mostly shown negative findings in previous studies (Alon \& Hageman, 2013; Faa, 2008; Frey \& Torgler, 2007; Torgler, 2012). Aligning to social influence, the Zakah payers' (business owners) compliance behavior is posited to be changed according to peers' attitude and behavior. Hence, it is hypothesized that:

H3. Peer influence has a negative influence on business Zakah compliance.

\section{Research Method}

This study focused on perception of Zakah payers toward compliance with Zakah laws provided by the official authority. Data of the study were collected via a self-administered questionnaire distributed to the participants. Specifically, the questionnaires of this study were distributed to business owners in Yemen, consisting of businesses that are eligible to pay business Zakah and who own enterprises registered with the Federation of Yemen Chambers of Commerce and Industry (FYCCI) (2016). Thus, the population of this study consists of 56,326 businesses operating in the country. In reference to Krejcie and Morgan (1970)'s table of sample, the appropriate sample size of the study is 382 . The sample size was increased to 500 to take care of the potential non-response rate (Israel, 2009). Thus, a total of 287 responses were retrieved with response rate of $57 \%$. However, 13 questionnaires were found to be problematic and were discarded accordingly, leaving 274 usable questionnaires for further analysis. This response rate is considered to be sufficient for survey analysis, as it met the rule of thumb of Sekaran (2003).

\subsection{Measurement Instrument}

The survey instrument developed for the present study comprises of 19 measurement items. The measurement items were adapted from prior studies. Particularly, four measurement items were adapted from Saad and Haniffa (2014) to measure compliance behavior with Zakah law, law enforcement (four items) from Idris (2002), Islamic religiosity (six items) from Alam et al. (2012) and peer influence (five items) from Bobek et al. (2013). The respondents were asked to indicate their agreement or disagreement with several statements on a five-point Likert scale (from strongly disagree " 1 " to strongly agree " 5 "). To test the appropriateness of the instrument of this study, a pilot study was conducted and led to detection, removal and adjustment of ambiguities in the instrument. Accordingly, based on pilot study result, minor amendments were made to the questionnaire prior to conducting the main study. 


\subsection{Data Analysis Technique}

Data collected was analyzed with Partial Least Squares Structural Equation Modeling (PLS-SEM). This study chose PLS-SEM as an analytical tool because the aim of the study is to predict the relationships among multiple latent constructs (Hair et al., 2017). PLS-SEM further exhibits a higher level of statistical power than Covariance-Based Structural Equation Modeling (CB-SEM) (Hair et al., 2011). As suggested by Hair et al. (2017) and Cain et al. (2016), multivariate skewness and kurtosis were examined using software named Web Power and available at: https://webpower.psychstat.org/models/kurtosis/. The outcome showed that the data collected of the current study was not multivariate normal; the Mardia's multivariate skewness $(\beta=3.486, p<0.01)$ and Mardia's multivariate kurtosis $(\beta=26.038, p<0.05)$. This result confirmed the non-normality, consequently, the study continued to use Smart-PLS, which is a non-parametric analysis technique (Ramayah et al., 2017).

\section{Results and Discussion}

The demographic characteristics of the sampled business owners are presented in Table 1. As noted in the table, among 274 business owners, $88 \%$ were 30 years and above. As for gender, a large majority of respondents (88\%) were male, and $67 \%$ of business owners were married. For education, more than half of them gave their level of education as up to secondary school certificate. Around $82 \%$ of the selected businesses had been operating for 5 years and above.

Table 1. Summary of respondents' profile

\begin{tabular}{llll}
\hline Demographic characteristics & Sub-characteristics & $n$ & $\%$ \\
\hline Age (years) & Less than 30 & 32 & $12 \%$ \\
\cline { 2 - 4 } & $30-39$ & 75 & $27 \%$ \\
\cline { 2 - 4 } & $40-49$ & 123 & $45 \%$ \\
\cline { 2 - 4 } & 50 and above & 44 & $16 \%$ \\
\hline Gender & Male & 241 & $88 \%$ \\
\cline { 2 - 4 } Marital status & Female & 33 & $12 \%$ \\
\hline Education level & Single & 50 & $18 \%$ \\
\cline { 2 - 4 } & Married & 184 & $67 \%$ \\
\cline { 2 - 4 } & Others & 40 & $15 \%$ \\
\hline Period of business & Up to secondary school certificate & 148 & $54 \%$ \\
\cline { 2 - 4 } & Diploma certificate & 56 & $20 \%$ \\
\cline { 2 - 4 } & Bachelor's degree and above & 70 & $26 \%$ \\
\hline & Less than 5 & 51 & $18 \%$ \\
\cline { 2 - 4 } & $5-10$ & 94 & $34 \%$ \\
\cline { 2 - 4 } & $11-15$ & 50 & $18 \%$ \\
\cline { 2 - 4 } & More than 15 & $30 \%$ \\
\hline
\end{tabular}

In this study, results of PLS-SEM are evaluated based on two main stages; the assessment of measurement model (outer model) and the assessment of structural model (inner model) (Hair et al., 2017; Henseler et al., 2009).

\subsection{Measurement Model}

Measurement model aims to establish the validity and reliability of the constructs' items. According to Hair et al. (2017) and Henseler et al. (2009), there are four criteria can be employed to assess the measurement model of the study. The analysis comprises of individual indicator reliability (item loading: loading must be higher than 0.40 ), internal consistency reliability (Cronbach's Alpha (CA) and Composite Reliability (CR): both must exceed 0.70), convergent validity (Average Variance Extracted (AVE): must be greater than 0.50) and discriminant validity (cross loading: latent variable' loading should be greater than another variable, Fornell-Larcker criterion: square root of 
AVE of variable must be higher than its square correlation with other variables, and Heterotrait-Monotriat ration (HTMT): must be below than 0.85).

\subsubsection{Individual Item Reliability}

This main purpose of individual item reliability is to assess the extent to which an item or set of items is consistent with what it supposes to measure (Urbach \& Ahlemann, 2010). Hair et al. (2017) and Hulland (1999) suggested that the threshold of this criterion is 0.40 and any item less than this value must be deleted. However, other researchers stated that "loading between 0.40 and 0.70 must be considered for removal if deleting an item will increase CR or AVE" (Hair et al., 2014; Henseler et al., 2009). In the current study, the results of PLS algorithm obtained that one item of Islamic religiosity (IR5) loaded extremely poor. Thus, the removal of this item increased the values of CR and AVE, as presented in Table 2.

\subsubsection{Internal Consistency Reliability}

Internal consistency reliability is defined as the degree to which all indicators on a certain scale measuring the similar variable. CA, in the past, was used to assess this kind of criteria. CA recently criticized as it assumes that all indicators are equally reliable and have equal loading on the latent construct neglecting the individual items reliability (Hair et al., 2017). Therefore, CR is regarded as the more appropriate technique to measure internal consistency reliability (Hair et al., 2017). Interestingly, the results of PLS algorithm in the present study demonstrated that CA and CR values of all latent variables loaded from 0.729 to 0.903 and from 0.831 to 0.928 respectively (see Table 2). Thus, all the latent variables under study have met and exceeded the acceptable threshold of reliability (0.70). The internal consistency of items, therefore, was confirmed.

\subsubsection{Convergent Validity}

This type of measurement criteria refers to the extent to which a set of items can measure the same latent variable in agreement (Henseler et al., 2009). To assess convergent validity, Hair et al. (2014) and Valerie (2012) suggested the test of AVE with the threshold of at least 0.50 or greater. It means that a latent variable must at least be able to explain half or more of the indicators' variance. For the purpose of the current study, the values of AVE for all constructs were between 0.551 and 0.721 (see Table 2). Hence, the findings of AVE test of the study have exceeded the advised cut-off value of 0.50 , indicating a satisfactory convergent validity.

Table 2. Reliability and validity

\begin{tabular}{|c|c|c|c|c|c|}
\hline Construct & Items & Loadings & $\mathrm{CA}$ & $\mathrm{CR}$ & AVE \\
\hline \multirow[t]{4}{*}{ Business Zakah compliance (BZC) } & $\mathrm{BZC1}$ & 0.713 & 0.729 & 0.831 & 0.551 \\
\hline & BZC2 & 0.732 & & & \\
\hline & BZC3 & 0.769 & & & \\
\hline & BZC4 & 0.754 & & & \\
\hline \multirow[t]{4}{*}{ Law enforcement (LEn) } & LEn1 & 0.865 & 0.834 & 0.874 & 0.636 \\
\hline & LEn2 & 0.738 & & & \\
\hline & LEn3 & 0.736 & & & \\
\hline & LEn4 & 0.843 & & & \\
\hline \multirow[t]{5}{*}{ Islamic religiosity (IR) } & IR1 & 0.793 & 0.903 & 0.928 & 0.721 \\
\hline & IR2 & 0.900 & & & \\
\hline & IR3 & 0.815 & & & \\
\hline & IR4 & 0.870 & & & \\
\hline & IR6 & 0.864 & & & \\
\hline \multirow[t]{5}{*}{ Peer influence (PI) } & PI1 & 0.814 & 0.874 & 0.910 & 0.674 \\
\hline & PI2 & 0.918 & & & \\
\hline & PI3 & 0.917 & & & \\
\hline & PI4 & 0.773 & & & \\
\hline & PI5 & 0.651 & & & \\
\hline
\end{tabular}




\subsubsection{Discriminant Validity}

Discriminant validity refers to the extent to which indicators differentiate across constructs. In other words, it implies that the degree to which a construct under study is truly distinct from one another (Henseler et al., 2009). There three criteria to assess discriminant validity (Hair et al., 2017), namely, Fornell and Larcker's (1981) criterion, cross-loading and HTMT. In the first method, Fornell and Larcker assessment is evaluated by comparing square roots of AVE with correlations among latent variables (Fornell \& Larcker, 1981); when the square root of AVE of a construct is higher than other constructs' square correlation. Therefore, the present study's results showed that all square root of AVE ranged between 0.742 and 0.849. As displayed in Table 3, the results indicated that the discriminant validity of out model was confirmed.

Table 3. Discriminant validity (Fornell-Larcker criterion)

\begin{tabular}{lllll}
\hline Construct & BZC & LEn & IR & PI \\
\hline BZC & $\mathbf{0 . 7 4 2}$ & & & \\
\hline LEn & 0.149 & $\mathbf{0 . 7 9 7}$ & & \\
\hline IR & 0.356 & 0.129 & $\mathbf{0 . 8 4 9}$ & \\
\hline PI & -0.503 & -0.069 & -0.108 & $\mathbf{0 . 8 2 1}$
\end{tabular}

Note: Value in the diagonals cell (bold) represents the square root of AVE

Another criterion to evaluate discriminant validity is cross-loading assessment (Chin, 1998). Based on suggestion of Hair et al. (2017), the loading of a certain variable must load higher than the cross-loading of other variables. In the current study, as clearly presented in Table 4, all loadings of the measurement items were higher than any other cross-loadings, indicating that discriminant validity of the model has attained.

Table 4. Discriminant validity (cross-loading criterion)

\begin{tabular}{lllll}
\hline Items & BZC & LEn & IR & PI \\
\hline BZC1 & $\mathbf{0 . 7 1 3}$ & 0.059 & 0.250 & -0.391 \\
\hline BZC2 & $\mathbf{0 . 7 3 2}$ & 0.110 & 0.219 & -0.330 \\
\hline BZC3 & $\mathbf{0 . 7 6 9}$ & 0.158 & 0.235 & -0.408 \\
\hline BZC4 & $\mathbf{0 . 7 5 4}$ & 0.112 & 0.344 & -0.358 \\
\hline LEn1 & 0.159 & $\mathbf{0 . 8 6 5}$ & 0.111 & -0.106 \\
\hline LEn2 & 0.041 & $\mathbf{0 . 7 3 8}$ & 0.068 & 0.014 \\
\hline LEn3 & 0.052 & $\mathbf{0 . 7 3 6}$ & 0.114 & -0.085 \\
\hline LEn4 & 0.133 & $\mathbf{0 . 8 4 3}$ & 0.111 & -0.009 \\
\hline IR1 & 0.310 & 0.137 & $\mathbf{0 . 7 9 3}$ & -0.081 \\
\hline IR2 & 0.339 & 0.103 & $\mathbf{0 . 9 0 0}$ & -0.124 \\
\hline IR3 & 0.253 & 0.125 & $\mathbf{0 . 8 1 5}$ & -0.044 \\
\hline IR4 & 0.344 & 0.064 & $\mathbf{0 . 8 7 0}$ & -0.137 \\
\hline IR6 & 0.232 & 0.136 & $\mathbf{0 . 8 6 4}$ & -0.043 \\
\hline PI1 & -0.349 & -0.057 & -0.102 & $\mathbf{0 . 8 1 4}$ \\
\hline PI2 & -0.444 & 0.004 & -0.090 & $\mathbf{0 . 9 1 8}$ \\
\hline PI3 & -0.459 & -0.017 & -0.068 & $\mathbf{0 . 9 1 7}$ \\
\hline PI4 & -0.376 & -0.076 & -0.024 & $\mathbf{0 . 7 7 3}$ \\
\hline PI5 & -0.410 & -0.146 & -0.155 & $\mathbf{0 . 6 5 1}$ \\
\hline & & & &
\end{tabular}


HTMT is the third method to evaluate discriminant validity (Hair et al., 2017; Henseler et al., 2015). It refers to the correlations within latent variables to correlations between the variables. Hair et al. (2017) states that HTMT is "an estimate of what true correlation between two constructs would be if they are perfectly measure". The cut-off value of the HTMT approach must be below 0.85 to achieve the discriminant validity (Kline, 2011). The result of HTMT in the present study, as illustrated in Table 5, showed that all values are less than the recommended threshold of 0.85 . Thus, the discriminant validity of all constructs has been established.

Table 5. Discriminant validity (HTMT criterion)

\begin{tabular}{lllll}
\hline Construct & BZC & LEn & IR & PI \\
\hline BZC & & & & \\
\hline LEn & 0.167 & & & \\
\hline IR & 0.426 & 0.148 & & \\
\hline PI & 0.625 & 0.105 & 0.120 & -- \\
\hline
\end{tabular}

In a nutshell, the overall results of measurement model of this study provide a clear evidence that all measurements in the path model have met the conventional standards of reliability and validity. Thus, this paves way for the second main step of analysis which involves the assessment of the structural model to determine the significance of the relationships and the developed hypotheses (Henseler et al., 2009).

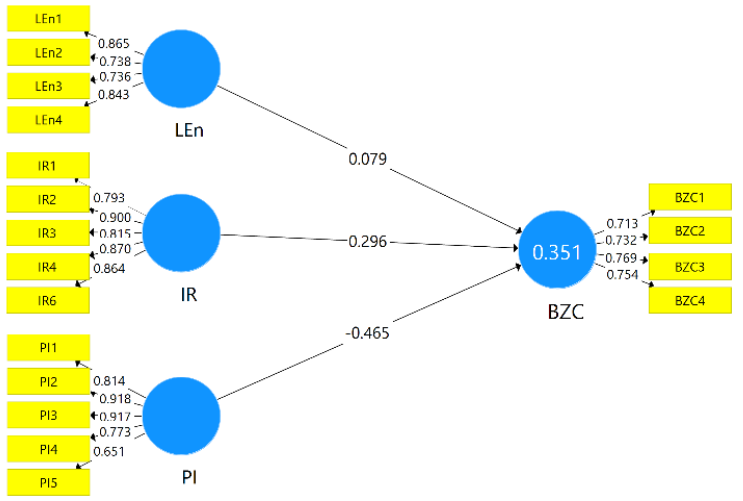

Figure 1. Measurement model of the study

\subsection{Structural Model}

The structural model is analyzed to test the impact or effect of the exogenous variables on the endogenous variable (Hair et al., 2017). The current study has three independent variables (law enforcement, Islamic religiosity and peer influence) and dependent variable of business Zakah compliance. Typically, structural model has four main criteria to be evaluated, are; variance explained $\left(R^{2}\right)$, effect size $\left(f^{2}\right)$, predictive relevance $\left(Q^{2}\right)$ and path coefficient $(\beta)$ and result of hypotheses testing (Chin, 2010; Hair et al., 2017; Henseler et al., 2009). Table 6 displays the results of the structural model of the current study, containing the four criteria for checking the study model.

Table 6. Structural model of the study

\begin{tabular}{llllllllll}
\hline Hypotheses & $\boldsymbol{\beta}$ & Std Error & $\boldsymbol{t}$-value & $\boldsymbol{p}$-value & Supported & $\boldsymbol{R}^{2}$ & $\boldsymbol{Q}^{2}$ & $\boldsymbol{f}^{\mathbf{2}}$ \\
\hline H1: & LEn -> BZC & 0.079 & 0.067 & 1.172 & 0.121 & No & 0.351 & 0.177 & 0.009 \\
\hline H2: & IR -> BZC & 0.296 & 0.055 & 5.397 & $0.000^{* * *}$ & Yes & & & 0.131 \\
\hline H3: & PI -> BZC & -0.465 & 0.044 & 10.505 & $0.000^{* * *}$ & Yes & & & 0.329 \\
\hline
\end{tabular}

Note: Significant at $* * * p<0.01$ (one-tailed test); BZC: business Zakah compliance; LEn: law enforcement; IR: Islamic religiosity; and PI: peer influence. 
From Table 6, the coefficient of determination $\left(R^{2}\right)$ of the endogenous latent variable is considered moderate and acceptable (Chin, 1998). The $R^{2}$ value, as also illustrated in Figure 1, implies that the three sets of exogenous latent collectively explained 35\% of the variance in business Zakah compliance. The change in the value of $R^{2}$ when a certain exogenous being omitted from the model is known as effect size $\left(f^{2}\right)$. It is interesting to note that peer influence had the biggest (medium) effect size in the model; with $f^{2}$ value of 0.329 . Followed by Islamic religiosity with a small $f^{2}$ value is 0.131 . While law enforcement had no influence on business Zakah compliance (0.009) in accordance with Cohen (1988)'s suggestion. For assessing the predictive accuracy of the model $\left(Q^{2}\right)$, the results showed that the path model's accuracy is acceptable with $Q^{2}$ value of 0.177 . As seen in Table 6 , the $Q^{2}$ value is greater than 0 , indicating the predictive relevance of factors (law enforcement, Islamic religiosity and peer influence) on Zakah payers' compliance behavior.

The final step is to assess the significance of the relationships and developed hypotheses. The findings of path model and hypotheses testing are exhibited in Table 6 and Figure 2. The first hypothesis examined the relationship between Zakah law enforcement and business owners' compliance behavior to comply with Zakah. Law enforcement had no relationship with business Zakah compliance $(\beta=0.079, t=1.172, p>0.05)$. Thus, the proposed hypothesis (H1) is rejected. However, the findings showed that Islamic religiosity has a significant positive influence on business Zakah compliance $(\beta=0.296, t=5.397, p<0.001)$. Accordingly, the hypothesis (H2) is statistically supported. Similarly, the results obtained also support for $\mathrm{H} 3$; there is a significant and negative relationship between peer influence and Zakah compliance of business owners in Yemen $(\beta=-0.465, t=10.505, p<0.001)$. Figure 2 shows the results of the study's structural model.

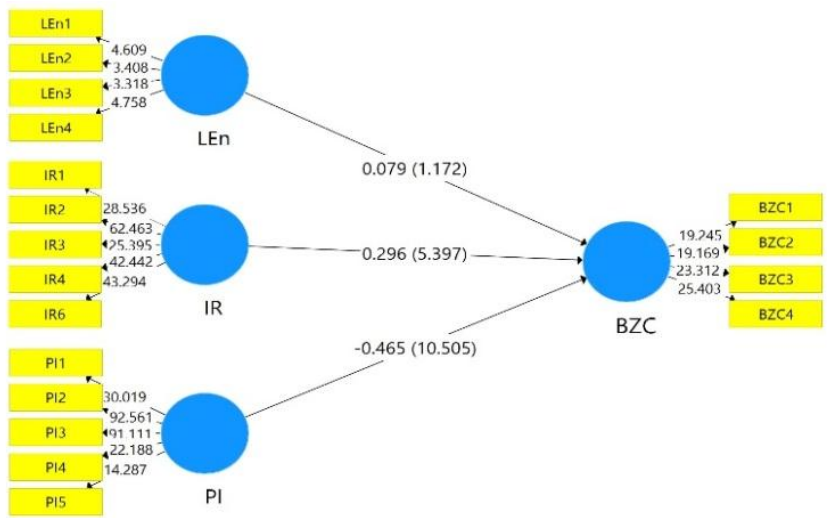

Figure 2. Structural model of the study

In light of the worsening poverty in Yemen (Bin-Nashwan, 2018), Zakah has unfortunately not succeeded in realizing its set out objectives as an effective tool in fighting poverty. As earlier discussed, with low compliance behavior, the collection of Zakah has continued to be low accordingly. Therefore, the present study sought to investigate in-depth the determinants of Zakah payers' compliance behavior with Zakah laws and instructions. The study has resulted in interesting findings. First, the perceived law enforcement had no influence Zakah payers' decision to comply with Zakah rules. This result is not surprising given some of the previous studies' results. For example, Ahmad et al. (2011); Idris (2006); and Zulkifli and Sanep (2010) have documented no effect of law enforcement on Muslims compliance behavior with Zakah obligation. Therefore, it can be concluded that this finding is an interesting discovery since it might play an important role in guiding the government, especially Zakah authorities in Yemen and other Muslim countries, to more enhance the voluntary compliance behavior rather than forcing people to pay the due Zakah.

Another finding revealed that business compliance behavior of Zakah payers is positively influenced by Islamic religiosity. That is, Zakah payers with high religious faith was shown compliant behavior to pay Zakah compare to those with low religious faith. The result is consistent with the past literature (Abdullah \& Sapiei, 2018; Azman \& Bidin, 2015; Idris et al., 2012). In a country like Yemen, as all its population are totally Muslims, it could provide a signal for Zakah authority to pay more intention on encourage Zakah payers' religious values. Further, the result is useful to other Muslim communities.

Lastly, this study also showed that the relationship between peer influence and business Zakah compliance of Zakah payers is significantly negative. The social psychologists have justified that honest people might be encouraged to 
conducted noncompliance behavior once they observe their peer and important reference group are engaging in the same activities (Chan et al., 2000; Spicer \& Becker, 1980). Importantly, the finding of this study is not isolated because it is consistent with the prior studies (Alon \& Hageman, 2013; Faa, 2008; Frey \& Torgler, 2007; Torgler, 2012).

\section{Conclusions, Implications and Future Research Direction}

This study examined the influence of law enforcement, Islamic religiosity and peer influence on business Zakah compliance. Consistent with previous studies, the current study pointed out that Islamic religiosity has a significant positive influence on Zakah payers' decision to comply with Zakah laws, demonstrating that those Muslims who highly religious are more likely to comply with Zakah. Peer influence also showed a significant relationship with Zakah payers (business owners) behavior of Zakah compliance but in a negative direction. This suggests that Zakah payers might be surrounded by noncompliant peer, whereby their compliance behavior negatively related with high peer influence. This study, however, does not find any significant relationship between law enforcement by authority and compliance behavior of Zakah payers. These results have advanced insights into which policy or strategy is actually relevant for understanding Zakah payers' compliance behavior, especially to encourage voluntary compliance rather than enforce compliance. The findings also are considerably recommended Zakah authorities, not only in Yemen but also in other Muslim countries, to develop policies based on determinants of compliance behavior. However, this study is not without limitation. The study has not exhausted the likely determinants that affect Muslims decision to comply with Zakah. Future research may expand the study model to cover more factors from economic and behavior perspectives.

\section{Acknowledgment}

The authors would like to express gratitude to Nahd Developemental Foundation, Yemen and Universiti Utara Malaysia for their continuous support in completing this research.

\section{References}

Abdullah, M., \& Sapiei, N. S. (2018). Do Religiosity, Gender and Educational Background Influence Zakat Compliance? The Case of Malaysia. International Journal of Social Economics, 45(8), 1250-1264. https://doi.org/10.1108/IJSE-03-2017-0091

Ahmad, S., Nor, N. G. M., \& Daud, Z. (2011). Tax-Based Modeling of Zakat Compliance. Jurnal Ekonomi Malaysia, 45(1), 101-108.

Ahmed, H. (2004). Role of Zakah and Awqaf in Poverty Alleviation. Occasional Paper No. 8, Islamic Research and Training Institute, Islamic Development Bank, Jeddah, Saudi Arabia.

Al Haq, M. A., \& Abd. Wahab, N. B. (2017). Effective Zakat Distribution: Highlighting Few Issues and Gaps in Kedah, Malaysia. Al-Iqtishad: Journal of Islamic Economics, 9(2), 259-288. https://doi.org/10.15408/aiq.v9i2.4002

Alam, S., Janor, H., Zanariah, C., \& Ahsan, M. (2012). Is Religiosity an Important Factor in Influencing the Intention to Undertake Islamic Home Financing in Klang Valley?. World Applied Sciences Journal, 19(7), 1030-1041.

Alon, A., \& Hageman, A. M. (2013). The Impact of Corruption on Firm Tax Compliance in Transition Economies: Whom Do You Trust?. Journal of Business Ethics, 116(3), 479-494. https://doi.org/10.1007/s10551-012-1457-5

Alosaimi, M. H., Bidin, Z., \& Derashid, C. (2017). Detection Risk and Penalty Magnitude and Zakah on Buisness Compliance: A Conceptual Model. International Business Management, 11(12), 2023-2025.

Al-Qardawi, Y. (2000). Fiqh al Zakah. A Comparative Study of Zakah, Regulation and Philosophy in the Light of Quran and Sunnah (1st ed.). Jeddah, Saudi Arabia: Scientific Publishing Centre King Abdul-Aziz University.

Azman, F. M. N., \& Bidin, Z. (2015). Factors Influencing Zakat Compliance Behavior on Saving. International Journal of Business and Social Research, 5(1), 118-128.

Bandura, A. (1977). Self-efficacy: Toward a Unifying Theory of Behavioral Change. Psychological Review, 84(2), 191-215. https://doi.org/10.1037/0033-295X.84.2.191

Bidin, Z. (2008). Faktor-Faktor Penentu Niat Gelagat Kepatuhan Zakat Pendapatan Gaji [Determinants of Compliance Intention on Income Zakah]. Unpublished Doctoral Thesis, Universiti Utara Malaysia.

Bidin, Z., \& Idris, K. M. (2007). A Confirmatory Analysis of Zakah Compliance Behavioural Intention on Employment Income. Malaysian Management Journal, 11(1\&2), 103-114. 
Bidin, Z., Idris, K. M., \& Shamsudin, F. M. (2009). Predicting Compliance Intention on Zakah on Employment Income in Malaysia: An Application of Reasoned Action Theory. Jurnal Pengurusan, 28, 85-102. https://doi.org/10.17576/pengurusan-2009-28-05

Bin-Nashwan, S. A. (2018). The Role of Non-governmental Organizations in the Reduction of Poverty: Case of NAHD Developmental Foundation. In 11th Annual Poverty and Social Protection Conference (9-11 March) (pp. 57-66). Bangkok, Thailand.

Bin-Nashwan, S. A., Abdul-Jabbar, H., \& Romle, A. R. (2016). The Application of Theory of Planned Behavior on Business Zakah Compliance in Yemen: A Proposed Framework. Middle-East Journal of Scientific Research, 24(6), 2052-2057.

Bin-Nashwan, S. A., Abdul-Jabbar, H., \& Romle, A. R. (2017). Perception of Business Owner toward Business Zakah Compliance Intention. World Journal of Islamic History and Civilization, 7(2), 17-22.

Bloodgood, J. M., Turnley, W. H., \& Mudrack, P. (2008). The Influence of Ethics Instruction, Religiosity, and Intelligence on Cheating Behavior. Journal of Business Ethics, 82(3), 557-571. https://doi.org/10.1007/s10551-007-9576-0

Bobek, D. D., Hageman, A. M., \& Kelliher, C. F. (2013). Analyzing the Role of Social Norms in Tax Compliance Behavior. Journal of Business Ethics, 115(3), 451-468. https://doi.org/10.1007/s10551-012-1390-7

Cain, M. K., Zhang, Z., \& Yuan, K. H. (2017). Univariate and Multivariate Skewness and Kurtosis for Measuring Nonnormality: Prevalence, Influence and Estimation. Behavior Research Methods, 49(5), 1716-1735. https://doi.org/10.3758/s13428-016-0814-1

Castro, L., \& Scartascini, C. (2015). Tax Compliance and Enforcement in the Pampas: Evidence from a Field Experiment. Journal of Economic Behavior \& Organization, 116, 65-82. https://doi.org/10.1016/j.jebo.2015.04.002

Chan, C. W., Troutman, C. S., \& O’Bryan, D. (2000). An expanded Model of Taxpayer Compliance: Empirical Evidence from the United States and Hong Kong. Journal of International Accounting, Auditing and Taxation, 9(2), 83-103. https://doi.org/10.1016/S1061-9518(00)00027-6

Chau, G., \& Leung, P. (2009). A Critical Review of Fischer Tax Compliance Model: A Research Synthesis. Journal of Accounting and Taxation, 1(2), 34-40.

Chin, W. W. (1998). The Partial Least Squares Approach to Structural Equation Modeling. In Mordern Methods for Business Research (pp. 295-336).

Chin, W. W. (2010). How to Write Up and Report PLS Analyses. Handbook of Partial Least Squares. Springer, Berlin, Heidelberg. https://doi.org/10.1007/978-3-540-32827-8_29

Cohen, J. (1988). Statistical Power Analysis for the Behavioral Sciences (2nd ed.). Lawrence Erlbaum Associates, Hillsdale.

Davis, J. S., Hecht, G., \& Perkins, J. D. (2003). Social Behaviours, Enforcement and Tax Compliance Dynamics. The Accounting Review, 78(1), 39-69. https://doi.org/10.2308/accr.2003.78.1.39

Diabi, A. (1993). The Concept of Zakah Evasion: An Economic Interpretation. Review of Islamic Economics, Leicester (U.K.), 2(2), 17-28.

Doktoralina, C. M., \& Bahari, Z. (2017). The Relationship between Income Household and Intention to Pay Zakat on Income among Indonesian Academicians. Mediterranean Journal of Social Sciences, 8(4), $27-39$. https://doi.org/10.1515/mjss-2017-0003

Faa, S. G. (2008). Tax Compliance Behaviour of Individuals under Self Assessment System. Unpublished Doctoral Thesis, Universiti Putra Malaysia.

Farah, J. M. S., Haji-Othman, Y., \& Omar, M. M. (2017). The Influence of Attitude, Religiosity, and Perception towards Law Enforcement on Intention towards Compliance Behaviour of Income Zakat among KUIN Staff in Kedah, Malaysia. International Journal of Muamalat, 1(1), 25-45.

Federation of Yemen Chambers of Commerce and Industry (FYCCI). (2016). Annual Report. Statistics of Registered Business Owners with Yemeni Chambers of Commerce and Industry. Retrieved from http://www.fycci-ye.org/ar/

Fornell, C., \& Larcker, D. (1981). Evaluating Structural Equation Models with Unobservable Variables and Measurement Error. Journal of Marketing Research, 18(1), 39-50. 
https://doi.org/10.1177/002224378101800104

Frey, B. S., \& Torgler, B. (2007). Tax Morale and Conditional Cooperation. Journal of Comparative Economics, 35(1), 136-159. https://doi.org/10.1016/j.jce.2006.10.006

Hair, J. F., Hult, G. T., Ringle, C. M., \& Sarstedt, M. (2017). A Primer on Partial Least Squares Structural Equation Modeling (PLS-SEM) (2nd ed.). London: Sage Publications. https://doi.org/10.15358/9783800653614

Hair, J. F., Ringle, C. M., \& Sarstedt, M. (2011). PLS-SEM: Indeed a Silver Bullet. The Journal of Marketing Theory and Practice, 19(2), 139-152. https://doi.org/10.2753/MTP1069-6679190202

Hair, J. F., Sarstedt, M., Hopkins, L., \& Kuppelwieser, V. (2014). Partial Least Squares Structural Equation Modeling (PLS-SEM): An Emerging Tool in Business Research. European Business Review, 26(2), 106-121. https://doi.org/10.1108/EBR-10-2013-0128

Haji-Othman, Y., \& Fisol, W. N. M. (2017). Islamic Religiosity, Attitude and Moral Obligation on Intention of Income Zakat Compliance: Evidence from Public Educators in Kedah. Journal of Academic Research in Business and Social Sciences, 7(2), 726-737. https://doi.org/10.6007/IJARBSS/v7-i11/3550

Heikal, M., Khaddafi, M., \& Falahuddin. (2014). The Intention to Pay Zakat Commercial: An Application of Revised Theory of Planned Behavior. Journal of Economics and Behavioral Studies, 6(9), 727-734.

Henseler, J., Ringle, C. M., \& Sarstedt, M. (2015). A New Criterion for Assessing Discriminant Validity in Variance-Based Structural Equation Modeling. Journal of the Academy of Marketing Science, 43(1), 115-135. https://doi.org/10.1007/s11747-014-0403-8

Henseler, J., Ringle, C. M., \& Sinkovics, R. R. (2009). The Use of Partial Least Squares Path Modeling in International Marketing. In New Challenges to International Marketing (Vol. 20, pp. 277-319). Emerald Group Publishing Limited. https://doi.org/10.1108/S1474-7979(2009)0000020014

Hulland, J. (1999). Use of Partial Least Squares (PLS) in Strategic Management Research: A Review of Four Recent $\begin{array}{lllr}\text { Studies. } & \text { Strategic } & \text { Management }\end{array}$ https://doi.org/10.1002/(SICI)1097-0266(199902)20:2<195::AID-SMJ13>3.0.CO;2-7

Idris, K. M. (2002). Gelagat Kepatuhan Zakat Pendapatan Gaji di Kalangan Kakitangan Awam Persekutuan Negeri Kedah [Income Zakah Compliance Behavior among Public Servants in the Federal State of Kedah]. Unpublished Doctoral Thesis, Universiti Utara Malaysia.

Idris, K. M. (2006). The Impact of Perception of Zakat Law and Enforcement towards the Obedient Behaviour of Zakat on Income. Journal of Ethics, Legal and Governance, 2, 32-41.

Idris, K. M., Bidin, Z., \& Saad, R. A. (2012). Islamic Religiosity Measurement and its Relationship with Business Income Zakat Compliance Behavior. Jurnal Pengurusan, 34, 3-10. https://doi.org/10.17576/pengurusan-2012-34-01

Israel, G. D. (2009). Sampling. University of Florida.

Kelman, H. (1958). Compliance, Identification, and Internalization: Three Processes of Attitude Change. Journal of Conflict Resolution, 2(1), 51-60. https://doi.org/10.1177/002200275800200106

Khamis, M. R., \& Yahya, N. C. (2015). Does Law Enforcement Influence Compliance Behaviour of Business Zakat among SMEs?: An Evidence via Rasch Measurement Model. Global Journal Al Thaqafah, 5(1), 19-32. https://doi.org/10.7187/GJAT752015.05.01

Kline, R. B. (2011). Principles and Practice of Structural Equation Modeling (3rd ed.). New York: Guilford Press.

Krejcie, R. V., \& Morgan, D. W. (1970). Determining Sample Size for Research Activities. Educational and Psychological Measurement, 30(3), 607-610. https://doi.org/10.1177/001316447003000308

Mohdali, R., \& Pope, J. (2014). The Influence of Religiosity on Taxpayers' Compliance Attitudes: Empirical Evidence from a Mixed-Methods Study in Malaysia. Accounting Research Journal, 27(1), 71-91. https://doi.org/10.1108/ARJ-08-2013-0061

Pope, J., \& Mohdali, R. (2010). The Role of Religiosity in Tax Morale and Tax Compliance. Australian Tax Forum, 25(4), 565-596.

Ramayah, T., Yeap, J. A., Ahmad, N. H., Halim, H. A., \& Rahman, S. (2017). Testing a Confirmatory Model of Facebook Usage in SmartPLS Using Consistent PLS. International Journal of Business and Innovation, 3(2), 
1-14.

Saad, R. A., \& Haniffa, R. (2014). Determinants of Zakah (Islamic Tax) Compliance Behavior. Journal of Islamic Accounting and Business Research, 5(2), 182-193. https://doi.org/10.1108/JIABR-10-2012-0068

Saad, R. A., Farouk, A. U., Wahab, M. S. A., \& Ismail, M. (2019). What Influence Entreprenuer to pay Islamic Tax (Zakat)?. Academy of Entrepreneurship Journal, 25(1), 1-13.

Sekaran, U. (2003). Research Methods for Business: A Skill Building Approach (4th ed.). New Jersey: John Wiley and Sons.

Sohag, K., Mahmud, K. T., Alam, F., \& Samargandi, N. (2015). Can Zakat System Alleviate Rural Poverty in Bangladesh? A Propensity Score Matching Approach. Journal of Poverty, 19(3), 261-277. https://doi.org/10.1080/10875549.2014.999974

Spicer, M. W., \& Becker, L. A. (1980). Fiscal Inequity and Tax Evasion: An Experimental Approach. National Tax Journal, 171-175.

The General Directorates of Zakah Obligations (GDZO). (2011). Annual Report of Zakah Resources. Sana'a, Yemen: GDZO Central Office.

The General Directorates of Zakah Obligations (GDZO). (2014). Annual Report of Zakah Resources. Sana'a, Yemen: GDZO Central Office.

The General Directorates of Zakah Obligations (GDZO). (2016). Annual Report of Zakah Resources. Sana'a, Yemen: GDZO Central Office.

Torgler, B. (2006). The Importance of Faith: Tax Morale and Religiosity. Journal of Economic Behavior \& Organization, 61(1), 81-109. https://doi.org/10.1016/j.jebo.2004.10.007

Torgler, B. (2012). Tax Morale, Eastern Europe and European enlargement. Communist and Post-Communist Studies, 45(1-2), 11-25. https://doi.org/10.1016/j.postcomstud.2012.02.005

Urbach, N., \& Ahlemann, F. (2010). Structural Equation Modeling in Information Systems Research Using Partial Least Square. Journal of Information Technology Theory and Application, 11(2), 5-40.

Valerie, F. (2012). Re-Discovering the PLS Approach in Management Science. Management, 15(1), $101-123$.

Wahab, N. A., \& Rahman, A. R. A. (2011). A Framework to Analyse the Efficiency and Governance of Zakat Institutions. Journal of Islamic Accounting and Business Research, 2(1), 43-62. https://doi.org/10.1108/17590811111129508

Zulkifli, D., \& Sanep, A. (2010). Legislation Impact on Compliance Zakat Payment towards Effective Strategies Zakat Collection Management Program. The 4th International Islamic Development Management Conference, Universiti Sains Malaysia. 